\title{
chapter Ken Clarke in Conversation ( with Peter Tyrer: My Role $\checkmark$ in Justice and Health
}

\author{
Peter Tyrer
}

\section{Introduction}

This interview was carried out with Ken Clarke on 24 September 2019 at the House of Commons. It was transcribed and subsequently edited by Ken and this text is placed in italics. The remainder of the text is written by Peter Tyrer.

\section{Early Background}

Ken Clarke and I were at the same Cambridge College, Gonville and Caius College, between 1959 and 1962. In the first year, we were in adjacent blocks in Tree Court, a square that is now deprived of trees but still has marvellous wisterias on the walls. Our paths hardly ever crossed. Ken soon became very involved in university politics and I was too preoccupied in organising a botanical expedition to Central Africa. Ken was attracted to Labour at first - his grandfather was a Communist - but then quickly changed to another party whose nature all now know. He was offered his place at Caius before being offered an Exhibition at Oxford University, which he turned down as he felt they were too pompous. Some jokers have suggested this was the reason Ken never became prime minister, as eleven of the last fourteen occupants of the position went to Oxford. The last to be educated at Cambridge was Stanley Baldwin.

The only other point of note that struck me when Ken was at Cambridge was his accent. He came from Langley Mill, a village that is in the middle of D. H. Lawrence country. Although he won a scholarship to Nottingham High School, very eminent in the Midlands, he must have had a fair dose of the typical and not unpleasant local accent and would have understood that 'silin' dahn in Stabbo' meant it was raining very hard in Stapleford (also near the Derbyshire border). He got on very well with the local miners, including those who had known D. H. Lawrence's father. Ken's father's associates did not think much of D. H. Lawrence, who they felt had got above himself by going away and 'writing mucky stories', so this gives you an idea of Ken's social milieu.

By the time he went to Cambridge, however, he was determined to become an MP and his accent had to change (remember this was 1959). He developed a Bertie Woosterish lad-di-dah accent with exaggerated rounded diphthongs, but this quickly changed into the voice everyone now knows. Ken is the only politician to be described as 'blokeish', a term impossible to define, but I think it really describes his voice. He doesn't talk down to people in any way and, even when disagreeing strongly, he retains the 'I'm just an ordinary chap trying to get my point over' that never sounds offensive. Mrs Thatcher had to have elocution lessons but from his early time in politics Ken never needed them. 
The main point of describing this background is to show Ken is not your ordinary politician. He achieved almost all the top positions of state - failing to be elected leader of the Conservative Party on three occasions - and could be regarded overall as highly successful, through dint of great intelligence and very hard work. He was constantly amazed at how lazy and ill-informed so many of his colleagues were.

\section{Consistency}

The other thing that is important to emphasise in understanding Ken Clarke is his consistency. It is often said that politicians have to bend in the wind or be toppled, but Ken was an exception. Once he had come to a view, he held on to it unless there was compelling evidence otherwise. The main reason I suspect why he was not elected leader of the Conservative Party was his belief that the UK should be an intrinsic part of the European Community. Unlike many other politicians who changed their views greatly over the years, Ken stuck to his opinion and, if anything, has stressed it even more strongly in these Brexit years.

In his personal life, he has been equally consistent. He was married to Gillian, whom he met as an undergraduate when at Caius, for more than fifty years. She died in 2015 from cancer, and one of her last acts was to vote for her husband in the 2015 General Election. She was an absolute rock to him, especially in his early political years when he commuted between Nottingham and London almost daily.

$\mathrm{He}$ is even consistent in his support of football teams. He supports both Notts County and Nottingham Forest and tries to see one of them every Saturday (they play at home alternately); he has kept loyal to both. Even though Notts County has drifted down the leagues and is in danger of going into liquidation, while Nottingham Forest soared to great heights in the 1970s and won the European Cup twice, he has stuck with both teams.

\section{Good Humour and Unflappability}

In his memoir, Kind of Blue, ${ }^{1}$ beautifully reflecting both his love of jazz and his semidetached connection with the Conservative Party, Ken several times refers to the very true perception that 'I was so laid back I was almost horizontal'. He is not wounded by criticism his wife was and tried to defend him - but he regards it as useful ammunition for his rejoinders, which are often very witty. His negotiations with the British Medical Association (BMA) over a new contract and negotiations for an internal market involved the chairman, Anthony Grabham, ${ }^{2}$ and Ken used to point out his name repeatedly to illustrate that doctors were only interested in their wallets. Yet he also agreed that the BMA, in the end, had won the public relations battle over the new contract, and in my interview with him he conceded that the BMA was the union that he felt was more formidable than any other trade union because it could use the public as its main ally (see also Chapter 28).

\section{Relevance of These Characteristics to Negotiations in Mental Health}

I do not share the political views of Ken Clarke and it is equally possible to describe him as a highly intelligent but blinkered politician who has always seen the world through a kind of blue lens. Yet, in the interview, I conducted with him he was absolutely straight. 'Go ahead, start your recording, ask me anything you want.' I have to praise that in a politician. The changes he made to the transcript were very small, essentially typographical errors and 
improvement of clumsy expressions; and never once did he say 'I've changed my mind over that now' - consistency or stubbornness, you decide.

Ken was also highly regarded as a constituency MP. He represented the parliamentary constituency of Rushcliffe to the east of Nottingham for forty-nine years and improved the lot of his constituents greatly over that time. (I know, as I look over with envy from where I live in the adjacent constituency of Newark, which has been much less successful in gaining funding and new initiatives.) This constituency includes Saxondale Hospital, the former county mental hospital of Nottinghamshire, and Ken was aware of its assets and its failings. What he found most disturbing when Saxondale Hospital was destined to close was what he thought was sound evidence that some of the county dignitaries had managed to place their difficult and embarrassing relatives in the hospital for no good reason and that they had languished there for years.

\section{My Interview}

I was far from clear that I would be allowed to tape the interview with Ken when I saw him and only had a few notes jotted down. I was also limited by time. I saw him in Portcullis House, the new base for politicians opposite Big Ben, and he had to return to the House of Commons for a vote on the same evening. I apologise for any important omissions.

Q. Why did you introduce NHS Trusts?

One of the things I was concerned about when I became Secretary of State was to try and make the service much more accountable to its patients, and to stop it being so borne down by bureaucracy and dominated by industrial relations problems. The whole point of the purchaser/provider divide was to make sure what money was being spent on locally and to spend that money on the best outcomes for patients, the service and others in that locality. The service was for the locality, a strikingly novel idea that caused a lot of controversy. I had to reform the awful way in which the service was managed, with the responsibility diffusing out from the centre, not very effectively, saying how the service should be run in the rest of the country. We needed a better way of doing things. The idea of Trusts was to give more autonomy to the local users of services so they could answer for their performances to their local public.

I intended to pass responsibility downwards from oversized headquarters in London and secure accountability upwards so the general public could see where decisions were made. This led to some interesting battles over the next three years but it generally went well.

Q. Was there ever a real risk that the John Moore proposal to have an insurance-based replacement for the NHS was likely to happen? ${ }^{3}$

There definitely was. If John Moore had not become unwell, the proposal would have gone ahead as Margaret Thatcher and John were quite agreed that this was precisely what they were going to do. She was convinced the American system was much superior to our own, with a system of personal insurance and the state paying the insurance premiums for those who could not afford it. When I became Secretary of State I quickly became aware that I was expected to take over the implementation of this policy. 
But I quickly came round to the view that this was quite unacceptable. Nigel Lawson helped me by resisting Margaret Thatcher's urgings, ${ }^{4}$ that those who paid these premiums could get tax relief on their private health insurance contributions. It took me many long meetings to persuade her (Margaret did listen to argument) to abandon her scheme, returning to mine that at least had a degree of market-related responsibility with a purchaser/provider split making sure that there was some fiscal discipline.

Before the purchaser/provider discussions nobody really knew that the NHS was spending its money on, and the idea that the money given might be linked to the outcomes was never contemplated. One trouble was that patients did not belong to any trade unions so their views about what was needed were never heard.

I never pretended I was introducing the final model for the National Health Service. I was wanting to change direction by putting in a framework that could be developed in the future. To some extent this has been achieved but now Simon Stevens of NHS England has developed the idea of integrating hospital and community care diluting the purchaser/ provider approach. ${ }^{5}$

Q. You mention in your memoirs that the BMA was the most difficult trade union you ever had to negotiate with. You were not very complimentary about the medical profession generally. Apart from Donald Acheson (then the Chief Medical Officer of Health), who you admired but who was not really part of the system, was there anyone in the BMA who you looked to for guidance and help?

Not really. Well the BMA was a trade union, even though at times they pretended not to be, with all sorts of high-minded statements for the general public, but basically, like all trade unions, they were always concerned about pay and conditions for their members. When I first arrived I was always advised I had to make concessions to the BMA. When I met Tony Grabham (muffled laughter about the significance of his surname) he tried to frighten me, telling me that all the previous Secretaries of State he had to deal with had all folded under the strain and that in the case of Barbara Castle he had reduced her to tears. But I wasn't going to buckle under this even when they got nasty and went public with advertisements pillorying $m e^{6}$

Q. Do you think doctors were treated too generously in the pay decisions of 2004 ?

Yes it was generous. And the government at the time, like almost all governments, was trying to buy popularity. Of course, as you know, the doctors have always been regarded as a special case. When Aneurin Bevan said you had to stuff their mouths with gold he set the scene for the future. When the new contracts set reduced hours for much of their work for more pay most were rather surprised as they were going to be paid more for doing less.

Q. Was the Conservative government involved in any way with the introduction of the Dangerous and Severe Personality Disorder Programme (DSPD) introduced by the Labour Government in 1999?

I have no recollection that at any time we were considering such a programme. I think you have to give the responsibility to the Labour government. The trouble is with policies like 
this is that you now have this semi-presidential system where everyone listens to advisers and so when public opinion gets sufficiently animated new policies are introduced without ever having been thought through. ${ }^{7}$

Q. What are your views about the Private Finance Initiatives (PFIs)?

We introduced the idea of Private Finance Initiatives in the 1992-7 government but very few took them on as the Labour Party said they would abolish them if they came to power. When of course they were elected they immediately started to introduce them. They have unfairly been given a very bad name. This is mainly because of the appalling incompetence of the people who negotiated these contracts, with payments that extended far beyond completion of the project. In the end they turned out to be more expensive than public financing. At the time there was this obsession over keeping to targets for the public finances. Gordon Brown was saying continuously in the first two to three years about how prudent he was going to be as Chancellor. ${ }^{8}$ But the government was not bothered about anything that was not on the books, so the PFIs were not down anywhere amongst the figures, so the government's reputation for fiscal prudence could not be damaged in any way. My only explanation why the health authorities were allowed to go mad on PFI contracts was that the responsibility for the payments would pass on to a Minister appointed many years into the future.

Q. Can I give you the example of one Trust close to me, Sherwood Forest Hospitals Foundation Trust, where the final bill for the new hospital is going to be more than thirty times the value of the initial cost. How could this happen?'

The problem was that the Trust people had no experience of any kind to negotiate the cost of such complex deals, so the people from these private organisations who negotiated these deals could not believe their luck, and took them to the cleaners. So the argument was quite simple. 'If you want your new hospital you can have it now. The payment for it will be made by someone else down the road, so don't worry.' So a sensible policy, well thought out and prudently applied at first, was quite discredited. Even in the early days when I was trying to get PFI going my approach was to say to each private financier that they could only get a return on their investment if they accepted a proportion of the risk.

The trouble was that the structure of these negotiations was quite unsuitable for the right contracts. People were appointed in the NHS with no experience, often on short-term contracts so they knew they would not have to pick up the flak down the line. So, in the Department of Health headquarters, we had some bright spark, hoping to make his way up the ladder, negotiating with British Oxygen's finest, knowing absolutely nothing about the oxygen market. So, as you can imagine, the results were very satisfactory for British Oxygen.

Q. Do you think there is a political solution to the imbalance in the funding of the NHS where a large proportion of the funding is going to elderly people like you and me, just to give them a few extra years of life, not always ideal ones, when it should be going to younger people with their lives ahead of them, including a large proportion with mental health problems? 
The reason why we have not been able to reverse this trend is that the people in the mental health system do not have a voice. I recognised this when I became Secretary of State and had to close down these Victorian institutions like Saxondale Hospital in my constituency, where people had been kept for years with no voice and no influence. These old 'asylums' were absolutely shocking places so it was perfectly sensible to introduce this policy of care in the community, provided it was integrated with hospital care by psychiatrists and others in a coherent way.

The trouble is that care in the community was extremely unpopular. People noticed that suddenly there were strange people out in the street loitering by traffic lights and felt that they ought to be locked away somewhere like Mapperley or Saxondale (if they were in Nottingham), ${ }^{9}$ and not being allowed to roam the streets.

The public believe that whenever there is extra money in the health service it ought to be spent on cancer patients or children, not on mental health, and populist Secretaries of State in populist governments accede to these requests, especially on cancer, a subject that terrifies the public so they feel if we spend more it might go away.

A more careful and balanced approach is possible but it does require a wellargued political defence. I separate that from the other problem you are touching on, which is the demographic one, the changing proportion of old and young people in society. The reason why there is an inexorable rising demand is the increasing age of the population that is creating a crisis in our health care system. We are going to have to find some way of meeting this demand. The burden of taxation is going to be spent increasingly on looking after the care of the elderly people and this is going to become unbalanced.

The big change is that so many people in their older years are going to need extra care. It is an extremely tricky political problem that has not been properly faced.

Q. But there has been an inter-Party group discussing this over some years. Is there any way in which this issue might be taken out of politics?

No, it can never be taken out of politics. The idea that it can be is quite wrong. Every time a bed-pan was dropped in South Wales there is a problem, which falls to the Secretary of State to deal with the consequences.

It will remain political while we have a totally free tax-paid health care system, even when it is linked to a social care system that is not comprehensively paid for at all by government.

\section{Q. Should the NHS take over social care?}

Well, we can't afford it. It's as simple as that. The debate about social care needs to be updated. It is perfectly obvious that if you provided the figures that would be necessary to pay for free care out of taxation it would be rejected out of hand. We need to introduce a more rational and fairer system. We need to come round to the idea that social care cannot be totally free and that we cannot avoid some financial burden. It may be possible to organise a national insurance system, but I'm not completely sure about that. We need to have something that takes account of the individual needs of patients and the responsibilities of society. The idea that somebody in a $£ 2 m$ house should not be expected to pay for the costs of their care is ridiculous. Yet if this person did pay something, it should 
not mean that someone on a low income who has worked and struggled to pay for their needs over a working lifetime should also be required to pay. This would be clearly farcical.

The reason why we do not have a policy on social care is that no government has had the courage to produce one. Although there have been many attempts to resolve this all of them have proved to be deeply unpopular.

The trouble with our current populist system of government is that all decisions seem to be made by opinion polls. But opinion polls change, so they are no substitute for a properly organised policy. Anyone who suggests that social care should be paid for completely out of taxation would not be able to defend this at a time when there is rapidly increasing demand. So you then have to work out what means testing you are going to apply. A fairer, but not instantly unpopular solution for the twenty-first century, is to have some private insurance arrangements set up for social care.

We have to recognise where we are now. Both our education and health care systems are immeasurably better that when I was Secretary of State. Now we want someone with a well-thought-out plan for longer term reform, someone who can put their head down and not be worried about being unpopular. One of the big things about Margaret Thatcher was that she was not terribly interested in the reactions of the general public, she never looked at popular opinion, as she was a conviction politician.

There are two rules that need to be understood about reform. First, all change is resisted at first, and second, that anything that might cost more money is equally resisted. So you have to be aware of that from the beginning when you are making changes.

Q. Lastly, I want to turn to your time when you were at the Ministry of Justice when you were trying very hard to bring down the prison population. Why has this been so difficult when in other countries this aim has been more successful?

It is very disappointing. Even in America, in places where they have hard-line Republicans, they are beginning to reduce incarceration rates. We should be able to do better.

Q. In current forensic practice there are strong moves to improve the environments of people with significant mental health problems and to obtain early release, but there are many obstructions in the way. What can we do to help here?

There are good people in correctional institutions who recognise that getting people out of prison into good environments is the key to progress. There are far too many people in our prisons who are mentally ill and who require the proper treatment for their conditions. Of course this sometime requires secure accommodation. But we have to acknowledge that our current prisons do not allow adequate intervention for any of the mental health issues that they face.

At present we are having another of these populist drives to be tougher on law and order so we can bring more people into overcrowded institutions where it is almost impossible to do any worthwhile therapeutic work with them. There isn't the space, there aren't the personnel and almost all the effort is wasted. Currently we have Priti Patel who is waving this banner to be 'tough on crime. ${ }^{10}$ But it started long before her. Michael Howard, David Blunkett and others did quite a lot to raise the prison population dramatically. ${ }^{11}$ 
Priti is going to do her best to make her policy at the next general election a repeat of the old 'hang 'em and flog 'em' mantra. But there have been reactions against this. Michael Gove was on our side; ${ }^{12}$ he had sensible solutions.

But, as for me, I have to say I failed to get a change in policy. I discussed it with David Cameron very frequently. ${ }^{13}$ He listened, but he was too nervous about the Daily Telegraph to do anything.

When we had the Thatcher government it was different. When we had good policies that we believed were right we implemented them. But we had to get the timing right. We knew they would be unpopular at first but over time they would be accepted, so we had to bring them in early. Nowadays parliaments seem to be much shorter. It is also different as Prime Ministers now employ ranks of public relations specialists who seem to make all the decisions.

\section{Q. Is there a place for conviction politics nowadays?}

Of course. The time will come again. I regard myself as a conviction politician but at present we are in a small minority.

\section{Conclusion}

The interview finished and Ken popped across to the House of Commons for one of his final debates. In the chaotic last weeks of the 2017-19 government, there was doubt as to who was running the country and one proposition put forward was that he, as Father of the House, might be prime minister for at least a week or so. It did not come to pass, but it would have been a fitting end to a career, which, despite the gloomy words of Enoch Powell that he maintained applied to all politicians, certainly did not end in failure.

\section{Notes}

1. K. Clarke, Kind of Blue: A Political Memoir. London: Pan Macmillan, 2016.

2. Sir Anthony Grabham (b. 19 July 1930; d. 21 February 2015) was a surgeon and chairman of the BMA when Ken was minister of health.

3. John Moore, Baron Moore of Lower Marsh (b. 26 November 1937; d. 20 May 2019) was secretary of state for health between 1987 and 1988. He was a great favourite of Mrs Thatcher and was often nicknamed 'Mr Privatisation', but this ended with his attempt to privatise the NHS.

4. Nigel Lawson, now Baron Lawson of Blaby, was financial secretary to the Treasury when Ken was minister of health. He subsequently became chancellor of the exchequer.

5. Sir Simon Stevens is chief executive of the NHS. He was health advisor to Tony Blair and Alan Milburn (former minister of health) for seven years and has been responsible for bringing independent organisations into the services of the NHS. This acknowledgement that John Moore may have abandoned the NHS as we know it was a revelation to me. Whatever one thinks of the internal market, and I for one feel it has failed and will need replacing in time, the possibility that the NHS principle of a service free at the point of need was so close to being lost is very alarming.

6. Barbara Castle, Baroness Castle of Blackburn (b. 6 October 1910; d. 3 May 2002) was secretary of state for health between 1974 and 1976. She introduced the first legislation to expand community care in the White Paper Better Care for the Mentally Ill (1975).

7. See Chapters 10 and 28. 
8. Gordon Brown was shadow chief secretary to the Treasury at the time in Ken's account. He subsequently became chancellor of the exchequer in the Labour government of 1997 and prime minister between 2007 and 2010.

9. Mapperley and Saxondale Hospitals were, respectively, the mental hospitals for the city of Nottingham and the county of Nottinghamshire. Ken was MP for a constituency in the catchment area of Saxondale Hospital.

10. Priti Patel has been home secretary since 2019. She is well known for being tough on criminals.

11. Michael Howard and David Blunkett were former home secretaries.

12. Michael Gove is currently chancellor of the Duchy of Lancaster and former education secretary.

13. David Cameron, leader of the Conservative Party (2005-16) and prime minister from 2010 to 2016. 